\title{
Antimicrobial Activities of Naphthalenylmethylen Hydrazine Derivatives
}

\author{
Hanif SHIRINZADEH ${ }^{*}$ \\ ${ }^{1}$ Department of Pharmaceutical Chemistry, Faculty of Pharmacy, Erzincan Binali Y1ldırım University, \\ Yalnizbag Yerleskesi 24100, Erzincan
}

Geliş / Received: 30/12/2020, Kabul / Accepted: 10/04/2021

\begin{abstract}
In clinical microbiology and antibacterial research, the significance of drug-resistant pathogens is growing up. Hydrazine-type compounds constitute the main classes of chemicals for the investigation of multidrug resistant agents which causes microbial infections. In the current study antimicrobial activities of twenty one Naphthalenylmethylen Hydrazine derivatives were examined to appraise their efficacy. The effectiveness of compounds were evaluated using 2-fold serial dilutions against Staphylococcus aureus, Methicillin-ResistantStaphylococcus aureus (MRSA), Enterococcus faecalis, Pseudomonas aeruginosa, Escherichia coli, and Candida albicans. Minimum inhibitory concentration (MIC) was determined for test compounds and for the reference standards ciprofloxacin, ampicillin, and miconazole. According to the results, although the tested compounds demonstrated poor antibacterial effects in general, the $\mathbf{1 e}$ and $\mathbf{1 h}$ compounds showed off significant antibacterial effects, especially against MRSA strains.
\end{abstract}

Keywords: Antimicrobial, Hydrazine, Indole, MRSA, Naphthalene

\section{Naftalenilmetilen Hidrazin Türevlerinin Antimikrobiyal Aktiviteleri}

\section{$\ddot{O} \mathbf{z}$}

Klinik mikrobiyoloji ve antibakteriyal araştırmalarda, ilaca dirençli patojenlerin önemi artmaktadır. Hidrazin tipi bileşikler, mikrobiyal enfeksiyonlarda çoklu ilaca dirençli ajanların araştırılması için önemli bir kimyasal sınıf olarak bilinmektedir. Bu çalışmada, belirli Naftalenilmetilen Hidrazin türevlerinin antimikrobiyal aktiviteleri incelenerek bu bileşiklerin etkinlikleri değerlendirilmiştir. Test edilen bileşiklerin antimikrobiyal etkinlikleri, 2-kat seri dilüsyon yöntemi kullanılarak, Staphylococcus aureus, Methicillin-ResistantStaphylococcus aureus (MRSA), Enterococcus faecalis, Pseudomonas aeruginosa, Escherichia coli ve Candida albicans'a karşı araştırılarak değerlendirilmiştir. Test edilen bileşiklerin Minimum İnhibisyon Konsantrasyonu (MIK), siprofloksasin, ampisilin ve mikonazol gibi standart referans bileşiklere karşı belirlenmiştir. Aktivite sonuçlarına göre, bileşikler genel olarak zayıf antibakteriyal etki göstermelerine rağmen, 1e ve 1h bileşikleri özellikle MRSA suşlarına karşı önemli antibakteriyal etki göstermişlerdir.

Anahtar Kelimeler: Antimikrobiyal, Hidrazin, İndol, MRSA, Naftalen

\section{Introduction}

In spite of great progress in pharmaceutical and medicinal chemistry, infectious diseases arising from bacteria, viruses, and fungi continue to be one of the most important hazards to public health. Although there are many antibacterial, antifungal, and antiviral drugs that are used effectively in the clinic, microorganisms have made these drugs ineffective/less effective within a short period of time because they have developed resistance against these drugs

\footnotetext{
*Corresponding Author:hanif.shirinzade@gmail.com
} 
(Puskullu et al., 2020; Blair et al., 2015). In addition, it is unavoidable for human beings to constantly confront new clinical findings emerging as a result of mutation of microorganisms. Covid-19, the latest rapidly developing infectious disease in worldwide is best example (Madabhavi et al., 2020; Spagnuolo et al., 2020). Particularly, prevalent drug resistance such as Methicillin-resistant Staphylococcus aureus (MRSA) is the main problem of our age (Blair et al., 2015; Taşci et al., 2018). Pneumonia, endocarditis, soft tissue and skin infections in intensive care units are among the serious infections caused by multidrug-resistant strains of MRSA (Shirinzadeh et al., 2018; Gordon et al., 2008; Okwu et al., 2019). The results of recent studies indicate that many Schiff's bases substituted with indole or indole isoester rings like naphthalene exhibit chemotherapeutic properties such as antituberculosis, antifungal, antiviral and antibacterial activities (Karali et al., 2007; Shirinzadeh et al., 2010; Bektas et al., 2010; Nastasa et al., 2018).

Hydrazine type compounds containing azomethine group constitute an important chemical class for new drug development (Shirinzadeh et al., 2020; Kumar et al., 2013), as well as many studies reported that compounds containing the Hydrazine group show high antimicrobial activity (Abdel-Fattah et al., 2000; Loncle et al., 2004). It has been contended that a some of hydrazine derivatives exhibit potent antibacterial-antifungal (Shirinzadeh et al., 2020) and antituberculosis activities (Sridhar et al., 2002; Maccari et al., 2005; Suriyati et al., 2007)

Previously, we reported antimicrobial activity of some indole derivatives against Staphylococcus aureus, MRSA, Escherichia coli, Bacillus subtilis, Enterococcus faecalis, Pseudomonas aeruginosa and Candida albicans strains. Consequently, most of the compounds showed an activity comparable with that of fluconazole, ampicillin, sultamicillin, ciprofloxacin (Shirinzadeh et al., 2011; Shirinzadeh et al., 2018).

One of the methods for developing the new drug is combining several pharmacophores in the same molecule which may lead to new compounds with remarkable biological activity. In our previous studies combination of indole and hydrazine-type compounds have demonstrated promising antibacterial activity especially against multidrug resistant microbial infections (Suriyati et al., 2007; Shirinzadeh al., 2011).

Therefore, based on previous studies, indole ring replaced with naphthalene ring which is bioisostere of indole. Thus, taking into consideration the results we obtained from previous studies, the antibacterial effectiveness of the indole ring will be understand more clearly (Shirinzadeh et al., 2018; Shirinzadeh et al., 2011). All of the tested compound in this study were synthesized and characterized on the basis of ${ }^{1} \mathrm{H},{ }^{13} \mathrm{C}$ NMR, mass spectra and elemental analysis. Thus, all data related on synthesis has been published (Shirinzadeh and Ghalia et al., 2020).

All compounds was tested against Staphylococcus aureus ATCC 29213, Staphylococcus aureus ATCC 43300 (MRSA), Enterococcus faecalis, Pseudomonas aeruginosa, Escherichia coli and Candida albicans utilizing the 2-fold serial dilution technique. In this way, for the test compounds and related reference standards (ciprofloxacin, ampicillin and miconazole) Minimum inhibitory concentration (MIC) was determined.

\section{Results and Discussion}

The MIC values of the tested compounds (Naphthalenylmethylene hydrazine derivatives) were determined against $S$. aureus, MRSA, E. faecalis, $P$. aeruginosa, E. coli and C. albicans 
strains. The obtained values were compared with the MIC values of ciprofloxacin, ampicillin and miconazole that used as standard drugs.

Most of the compounds demonstrated poor activity against S. aureus, MRSA, E. faecalis, P. aeruginosa, E. coli, and C. albicans compared to the indole derivatives that synthesized and evaluated in our previous study (Shirinzadeh et al., 2011; Shirinzadeh et al., 2018).

However, among these compounds, $\mathbf{1 e}$ and $\mathbf{1 h}$ compounds set outed acceptable antibacterial activity, especially against MRSA strains. In addition, unlike the indole derivatives synthesized previously, none of the naphthalene derivatives showed sufficient and promising antifungal activity against $C$. albicans. The MIC value of ciprofloxacin against MRSA strain was $0.626 \mu \mathrm{g} / \mathrm{mL}$, while the MIC of $\mathbf{1 e}$ and $\mathbf{1 h}$ compounds measured as $6.125 \mu \mathrm{g} / \mathrm{mL}$. However, compared to Ampicillin, ampicillin was ineffective against MRSA strains, while compounds 1e and $\mathbf{1 h}$ have inhibited MRSA strains as low concentration as $6.125 \mu \mathrm{g} / \mathrm{mL}$. when the most effective compounds $\mathbf{1 e}$ and $\mathbf{1 h}$ were compared with ampicillin and ciprofloxacin which were used as antibacterial standards, $\mathbf{1 e}$ and $\mathbf{1 h}$ compounds showed higher MIC values $(6,25 \mu \mathrm{g} / \mathrm{mL})$ compared to ciprofloxacin and low MIC values in contrast to ampicillin, especially against $M R S A$ and E. faecalis (Table 1).

Table 1. MIC values $(\mu \mathrm{g} / \mathrm{mL})$ of tested Naphthalenylmethylen hydrazine derivatives

\begin{tabular}{|c|c|c|c|c|c|c|c|c|c|c|c|c|c|}
\hline $\begin{array}{l}\text { Comp. } \\
\text { Code }\end{array}$ & 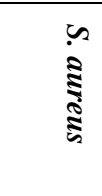 & $\underset{1}{3}$ & & 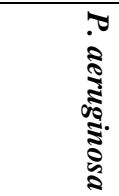 & $\begin{array}{l}1 \\
\vdots \\
\vdots\end{array}$ & 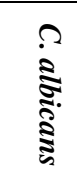 & $\begin{array}{l}\text { Com } \\
\text { Cod } \\
e\end{array}$ & 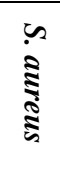 & $\underset{3}{3}$ & 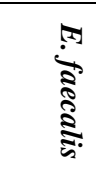 & 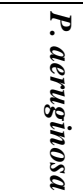 & $\begin{array}{l}\pi \\
\vdots \\
\vdots \\
\pi\end{array}$ & 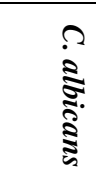 \\
\hline $1 a$ & 50 & 50 & 50 & 50 & 50 & 50 & 11 & - & 25 & 50 & 50 & 50 & 50 \\
\hline $1 b$ & - & 25 & 50 & 50 & 50 & 50 & $1 m$ & 50 & 50 & 50 & 25 & 50 & 50 \\
\hline $1 c$ & - & 50 & 50 & 50 & 50 & 50 & $1 n$ & 25 & 50 & 50 & 25 & 50 & 50 \\
\hline Id & 25 & 25 & 25 & 50 & 50 & 50 & 10 & - & - & 50 & 25 & 25 & 50 \\
\hline 1e & 12.5 & 6.25 & 25 & 50 & 50 & 50 & $1 p$ & 50 & 50 & 50 & 25 & 50 & 50 \\
\hline $1 f$ & 50 & 25 & 25 & 50 & 50 & 50 & $1 q$ & 50 & 50 & 25 & 50 & 50 & - \\
\hline $1 g$ & 25 & 50 & 25 & 50 & 50 & 50 & $1 r$ & 25 & 12.5 & 12.5 & 25 & 50 & 50 \\
\hline $1 h$ & 12.5 & 6.25 & 6.25 & 25 & 25 & 50 & $1 s$ & - & 50 & 50 & 50 & 50 & 50 \\
\hline $1 i$ & 25 & 12.5 & 12.5 & 25 & 25 & 50 & $1 t$ & 25 & 12.5 & 25 & 50 & 50 & 50 \\
\hline $1 j$ & 25 & 12.5 & 12.5 & 50 & 50 & 50 & $1 u$ & 25 & 50 & 50 & 25 & 50 & 50 \\
\hline $1 k$ & - & 50 & - & 50 & 50 & 50 & & & & & & & \\
\hline $\begin{array}{l}\text { Ciprofl } \\
\text { oxacin }\end{array}$ & 0.625 & 0.625 & - & 0.0097 & 0.625 & - & & & & & & & \\
\hline $\begin{array}{l}\text { ampicill } \\
\text { in }\end{array}$ & - & - & 0.19 & - & - & - & & & & & & & \\
\hline $\begin{array}{l}\text { micona } \\
\text { zole }\end{array}$ & - & - & - & - & - & 1.56 & & & & & & & \\
\hline
\end{tabular}




\section{Conclusion}

Previously, we carried out some studies on the antibacterial activities of various indolehydrazine derivative compounds. As a result, indole-hydrazine derivative compounds exhibited potent antibacterial activity (Shirinzadeh et al., 2011; Shirinzadeh et al., 2018). In the continuation of this research on Schiff bases, the naphthalene ring, which is the bioisostere of indole, was preferred as a new combination instead of indole. Thereby, we planned to gain insight into the importance of the indole ring in structure-activity evaluation. Indeed, based on this study, it was revealed that the Indole-hydrazine derivatives exhibited potent antibacterial activity than the naphthalene hydrazine derivatives. In addition, while the tested naphthalene derivatives did not show antifungal effects, indole derivatives demonstrated acceptable antifungal activities. It is believed the pyrrole ring in the indole structure might be one of the main reasons for the antifungal effect of indole derivatives.

According to the results of the study, although the tested compounds demonstrated poor antibacterial effects in general, the $\mathbf{1 e}$ and $\mathbf{1 h}$ compounds showed significant antibacterial effects, especially in the case of MRSA and E. faecalis strains.

It was observed that compounds 1e [1-(3-chlorophenyl)-2-((6-methoxynaphthalen-2-yl) methylene) hydrazine] and $\mathbf{1 h}$ [1-(2,4-dimethylphenyl)-2-((6-methoxynaphthalen-2-yl) methylene) hydrazine] have demonstrated an MIC value of $6.25 \mu \mathrm{g} / \mathrm{mL}$ against MRSA strains.

When we consider that ampicillin is ineffective against MRSA, these compounds stand out as showing excellent MIC values such a $6.25 \mu \mathrm{g} / \mathrm{mL}$. Therefore these compounds are promising to develop into more effective new lead compounds against MSRA and E. faecalis infections.

\section{Materials and Methods}

\subsection{Chemistry}

The designed compound was synthesized by condensation of phenylhydrazine with 6methoxy-2- naphthaldehyde or 2-naphthaldehyde (Kidwai et al., 1994). Twenty one tested compounds (Table 2) synthesized and spectroscopic analysis of them was done and published in our earlier study. The synthesized compounds were characterized on the basis of ${ }^{1} \mathrm{H}$ and ${ }^{13} \mathrm{C}$ NMR, mass spectra and elemental analyses (Shirinzadeh and Galia et al., 2020). 
Table 2 - Chemical structures of tested compounds

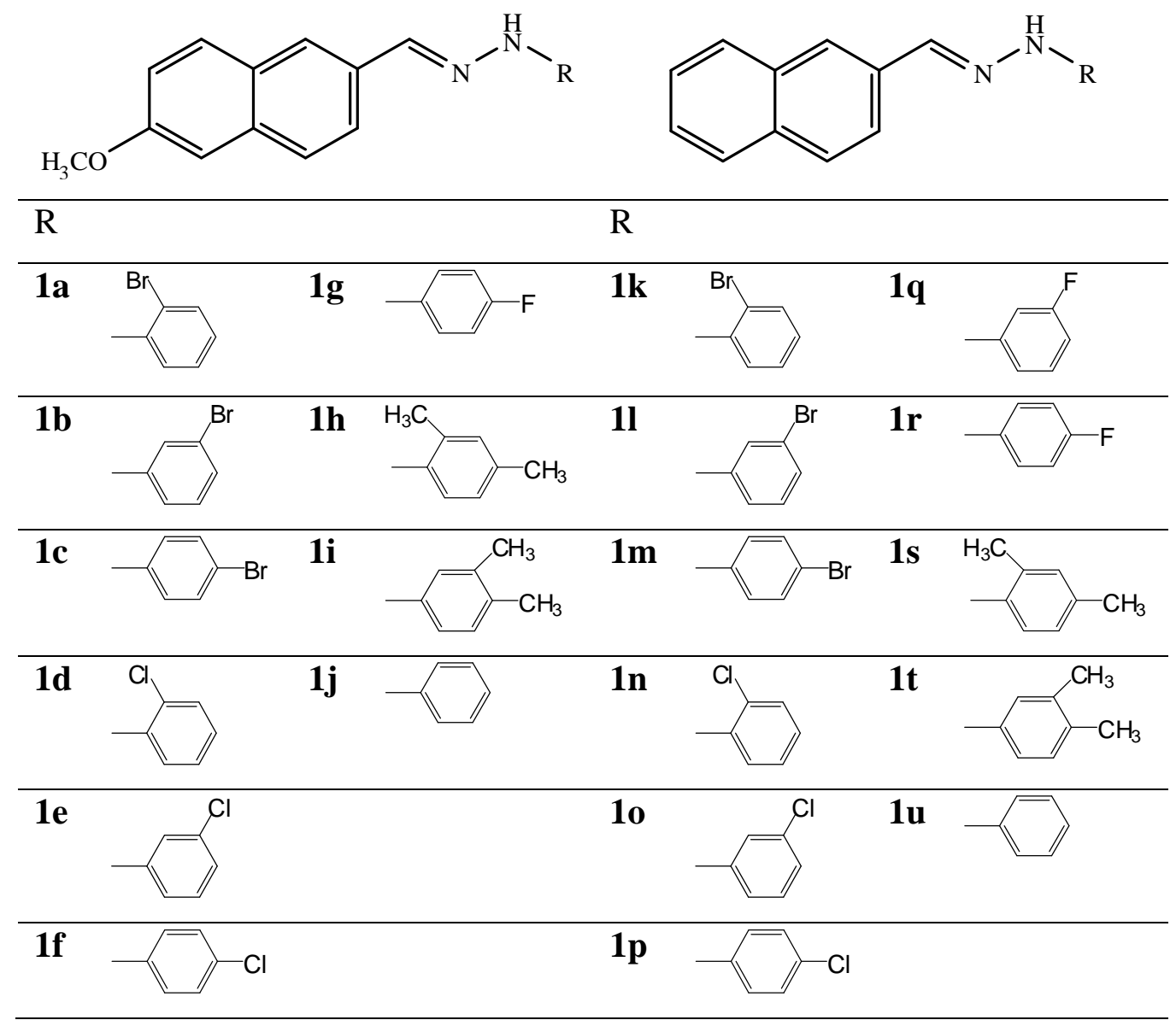

\subsection{Microbiology}

Antifungal and antibacterial activity assessments were carried out against standard strains. The American Type Culture Collection (ATCC) strains of the microorganisms utilized in the current research were received from the culture collection of the Refik Saydam Health Institution of Health Ministry, Ankara, and preserved at the Microbiology Department of the Faculty of Pharmacy of Ankara University. In order to grow and diluting of the microorganism suspensions, Mueller-Hinton broth (MHB) (Difco), Mueller-Hinton agar (MHA) (Oxoid), Sabouraud Dextrose agar (SDA) (Difco), and Sabouraud Dextrose broth (SDB) (Difco), were used. The following reference strains were used for testing antimicrobial activity: Gram-positive bacteria: Staphylococcus aureus ATCC 29213, Staphylococcus aureus ATCC 43300 (MRSA), Enterococcus faecalis ATCC 29212. Gram-negative bacteria: Escherichia coli ATCC 25922, Pseudomonas aeruginosa ATCC 27853. Yeast: Candida albicans ATCC 10231. 


\subsection{Antibacterial and Antifungal Activity Assay}

Fungi were protected on SDA for $48 \mathrm{~h}$ at $25^{\circ} \mathrm{C}$ and the bacterial strains were protected on MHA medium for $24 \mathrm{~h}$ at $37^{\circ} \mathrm{C}$. Overnight cultures were prepared by inoculating almost $2 \mathrm{~mL}$ MHB with 2-3 colonies of each organism taken from MHA. Inocula were prepared by diluting overnight cultures into $0.9 \%$ sterile saline solution until the visible turbidity was equal to 0.5 Mcfarland standard having approximately $108 \mathrm{CFU} / \mathrm{mL}$ for bacteria and 107 $\mathrm{CFU} / \mathrm{mL}$ for yeasts. The tube dilution technique was utilized for the determination of the MICs (CLSI; Wayne, PA,USA; 2009; CLSI document M27-A3; 2008). Naphthalenylmethylen hydrazine derivatives were researched to assess their effectiveness against multi-drug-resistant microbial infections by using the 2-fold serial dilution technique against $S$. aureus, MRSA, E. faecalis, $P$. aeruginosa, E. coli, and $C$. albicans. The synthesized compounds and standards were dissolved in $12.5 \%$ DMSO at concentrations of $200 \mu \mathrm{g} / \mathrm{mL}$. Further dilutions of the compounds and standard drugs in the test medium were prepared at the following quantities of $400,200,100,50,25,12.5,6.25,3.12,1.56$ and $0.78 \mu \mathrm{g} / \mathrm{mL}$ concentrations with MHB and SDB. A set of tubes containing only inoculated broth was used as controls. After incubation for $48 \mathrm{~h}$ at $25^{\circ} \mathrm{C}$ for the antifungal assay and $24 \mathrm{~h}$ at $37^{\circ} \mathrm{C}$ for the antibacterial assay, the last tube with no growth of yeast and/or microorganism was registered to represent the MIC (expressed in $\mu \mathrm{g} / \mathrm{mL}$ ). The MIC was determined for test compounds and for the reference standards Ciprofloxacin, ampicillin and miconazole (Shirinzadeh et al., 2018). Every experiment in the antifungal and antibacterial assays was performed in duplicate.

Acknowledgements: The chemical synthesis part of this work was supported by Scientific Research Council of Erzincan Binali Yildirim University under the Project No of SAG-A240215-0120. Furthermore author appreciate Prof. Dr. Nurten Altanlar for perform antibacterial activity tests.

\section{References}

Abdel-Fattah, M.E., Salem, E., Mahmoud, M.A. (2000). 'Synthesis and antimicrobial activity of some 3-p-chlorophenoxymethyl-4-phenyl-1,2,4-triazol-5-ylthio- acetyl hydrazine derivatives", Indian J. Heterocycl. Chem, 10, 121-128.

Bektas, H., Demirbas, A., Demirbas, N., Karaoglu, S.A. (2010). ''Synthesis of some new biheterocyclic triazole derivatives and evaluation of their antimicrobial activity", Turk. J. Chem, 34, 165-180.

Blair, J.M., Webber, M.A., Baylay, A.J., Ogbolu, D.O., Piddock, L.J. (2015). '’Molecular mechanisms of antibiotic resistance', Nat. Rev. Microbiol, 13(1), 42-51.

Clinical and Laboratory Institute. Methods for dilution antimicrobial susceptibility tests for bacteria that grow aerobically, Approved Standard. in: CLSI Publication M07-A10, Twelfth ed. CLSI; Wayne, PA,USA; 2009. 
Clinical and Laboratory Standards Institute (CLSI), Reference method for broth dilution antifungal susceptbility testing of yeasts; Approved Standart. Third ed. CLSI document M27A3. Wayne, PA, USA; 2008.

Gordon, R.J., Lowy, F.D. (2008). 'Pathogenesis of methicillin-resistant Staphylococcus aureus infection', Clin. Infect. Dis, 350-359.

Karali, N., Gursoy, A., Kandemirli, F., Shvets, N., Kaynak, F. B., Ozbey, S., Kovalishyn, V., Dimogloc, A. (2007). "'Synthesis and structure-antituberculosis activity relationship of $1 \mathrm{H}-$ indole-2,3-dione derivatives", Bioorg. Med. Chem, 15, 5888-5904.

Kidwai, M., Negi, N., Gupta, S.D. (1994). ' Synthesis and antifertility activity of 1,5-diaryl-3 (3 indolyl) formazans"', Chem Pharm Bull, 42(11), 2363-2364.

Kumar, P., Narasimhan, B. (2013). '"Hydrazides/hydrazones as antimicrobial and anticancer agents in the new millennium", Mini Rev Med Chem, 13(7), 971-87.

Loncle, C., Brunel, J.M., Vidal, N., Dherbomez, M., Letourneux, Y. (2004). 'Synthesis and antifungal activity of cholesterol-hydrazone derivatives', Eur. J. Med. Chem, 39, 1067-1071.

Maccari, R., Ottana, R., Vigorita, M.G. (2005). 'In vitro advanced antimycobacterial screening of isoniazid-related hydrazones, hydrazides and cyanoboranes Part 14', Bioorg. Med. Chem. Lett, 15, 2509-2513.

Madabhavi, I., Sarkar, M., Kadakol, N. (2020). 'COVID-19: a review', Monaldi Arch Chest Dis, 90(2). doi: 10.4081/monaldi.2020.1298.

Nastasa, D.C., Ionuţ, I., Stana, A., Benedec, D., Tamaian, R., Oniga, O., Tiperciuc, B. (2018). "Antibacterial Evaluation and Virtual Screening of New Thiazolyl-Triazole Schiff Bases as Potential DNA-Gyrase Inhibitors", Int J Mol Sci, 19(1), 222. doi: 10.3390/ijms19010222.

Okwu, M.U., Olley, M., Akpoka, A.O., Izevbuwa, O.E. (2019). 'Methicillin-resistant Staphylococcus aureus (MRSA) and anti-MRSA activities of extracts of some medicinal plants: A brief review", AIMS Microbiol, 5(2), 117-137.

Puskullu, M.O., Celik, I., Erol, M., Fatullayev, H., Uzunhisarcikli, E., Kuyucuklu, G. (2020). 'Antimicrobial and antiproliferative activity studies of some new quinoline- 3-carbaldehyde hydrazone derivatives", Bioorganic Chemistry, 101, 104014.

Shirinzadeh, H., Suzen, S., Altanlar, N., Westwell, D.A. (2018). 'Antimicrobial Activities of New Indole Derivatives Containing 1,2,4-Triazole, 1,3,4-Thiadiazole and Carbothioamide", Turk J Pharm Sci, 15(3), 291-297. 
Shirinzadeh, H., Altanlar, N., Yucel, N., Ozden, S., Suzen, S. (2011). "Antimicrobial Evaluation of Indole-Containing Hydrazone Derivatives', Z. Naturforsch, 66c, 340-344.

Shirinzadeh, H., Dilek, E. (2020). "Synthesis, characterization and biological activity evaluation of novel naphthalenylmethylen hydrazine derivatives as carbonic anhydrase inhibitors", Journal of Molecular Structure, 128657.

Shirinzadeh, H., Eren, B., Gurer-Orhan, H., Suzen, S., Ozden, S. (2010). ' Novel indole-based analogs of melatonin: Synthesis and in vitro antioxidant activity studies', Molecules, 15, 2187-2202.

Shirinzadeh, H., Ghalia, M., Tascioglu, A., Adjali, F.I., Gunesacar, G., Gurer-Orhan, H., Suzen, S. (2020). 'Bioisosteric modification on melatonin: synthesis of new naphthalene derivatives, in vitro antioxidant activity and cytotoxicity studies', Braz. J. Pharm. Sci, 56, 18124.

Spagnuolo, G., De Vito, D., Rengo, S., Tatullo, M. (2020). 'COVID-19 Outbreak: An Overview on Dentistry', Int J Environ Res Public Health, 17(6), 2094. doi: 10.3390/ijerph17062094.

Sridhar, S.K., Pandeya, S.N., Stables, J.P., Ramesh, A. (2002). 'Anticonvulsant activity of hydrazones, Schiff and Mannich bases of isatin derivatives', Eur. J. Pharm. Sci, 16, 129-132.

Suriyati, M., Pazilah, I., Habibah, A.W. (2007). ''Effects of isoniazid on viability, cell morphologies and acid fastness properties of Mycobacterium avium NCTC 8559 during the growth cycle"', Chemotherapy, 53, 263-266.

Taşci, M., Temiz-Arpaci, O., Kaynak-Onurdag, F., Okten, S. (2018). 'Synthesis and antimicrobial evaluation of novel 5-substituted-2-(p-tert-butylphenyl) benzoxazoles", Indian Journal of Chemistry Section B-Organic Chemistry Including Medicinal Chemistry, 385-389. 